\title{
Area Monitoring Dosimeter Program for the Pacific Northwest National Laboratory: Results for CY 1993 and CY 1994
}

S. R. Bivins

G. A. Stoetzel

March 1996

Prepared for the U.S. Department of Energy under Contract DE-AC06-76RLO 1830

Pacific Northwest National Laboratory Operated for the U.S. Department of Energy by Battelle

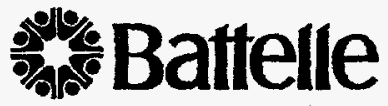





\title{
DISCLAIMER
}

This report was prepared as an account of work sponsored by an agency of the United States Government. Neither the United States Government nor any agency thereof, nor Battelle Memorial Institute, nor any of their employees, makes any warranty, express or implied, or assumes any legal liability or responsibility for the accuracy, completeness, or usefulness of any information, apparatus, product, or process disclosed, or represents that its use would not infringe privately owned rights. Reference herein to any specific commercial product, process, or service by trade name, trademark, manufacturer, or otherwise does not necessarily constitute or imply its endorsement, recommendation, or favoring by the United States Government or any agency thereof, or Battelle Memorial Institute. The views and opinions of authors expressed herein do not necessarily state or reflect those of the United States Government or any agency thereof.

\section{PACIFIC NORTHWEST NATIONAL LABORATORY operated by \\ BATTELLE MEMORIAL INSTITUTE for the \\ UNITED STATES DEPARTMENT OF ENERGY under Contract DE-ACO6-76RLO 1830}

\author{
Printed in the United States of America \\ Available to DOE and DOE contractors from the \\ Office of Scientific and Technical Information, P.0. Box 62, Oak Ridge, TN 37831; \\ prices available from (615) 576-8401.
}

Available to the public from the National Technical Information Service, U.S. Department of Commerce, 5285 Port Royal Rd., Springfield, VA 22161

This document was printed on recycled paper. 
3
$\vdots$
3
3

$\because$

$\therefore$

$\because$

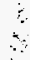


PNNL-11088

UC-600

\title{
Area Monitoring Dosimeter Program for the Pacific Northwest National Laboratory: Results for CY 1993 and CY 1994
}

\author{
S. R. Bivins \\ G. A. Stoetzel
}

March 1996

Prepared for

the U.S. Department of Energy under Contract DE-AC06-76RLO 1830

Pacific Northwest National Laboratory

Richland, Washington 99352

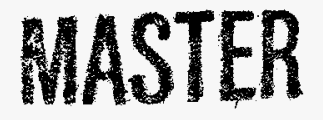




$$
1
$$

$\rightarrow$ 


\section{Summary}

In January 1993, Pacific Northwest National Laboratory (PNNL) established an area monitoring dosimeter program in accordance with Article 514 of the Department of Energy (DOE) Radiological Control Manual (RCM)(DOE 1994). The purpose of the program was to minimize the number of areas requiring issuance of personnel dosimeters and to demonstrate that doses outside Radiological Buffer Areas are negligible. Article 511.1a of the RCM requires issuance of personnel dosimeters if individuals are likely to receive a dose of at least 100 mrem annually.

Area thermoluminescent dosimeters (TLDs) were placed in PNNL facilities in accordance with the following guidelines:

- in all 300 Area PNNL facilities where staff work at least eight hours per month

- in all PNNL facilities where staff conduct radiological work (i.e., have a current Radiological Work Permit)

- in all PNNL facilities that are located within $15 \mathrm{~m}(\sim 50 \mathrm{ft})$ of another facility (including those of other contractors) that contains a radiological area, or an outdoor radiological area.

A total of 115 area TLDs were placed in PNNL facilities during CY 1993, and 118 area TLDs were placed during CY 1994. The TLDs were exchanged and analyzed quarterly with the exception of the second quarter TLDs for CY 1994, which were left in the field for six months through the end of the third quarter.

The area monitoring TLD program was a useful tool in determining exposure trends in work areas located outside of radiological areas. In several situations, the information obtained from this program was used to relocate staff or radioactive material resulting in potential dose reductions for staff.

All routine area monitoring TLD results were less than 50 mrem annually after correcting for worker occupancy. The results support the conclusion that personnel dosimeters are not necessary for staff in these monitored areas. 
. 


\section{Contents}

Summary $\quad \ldots \ldots \ldots \ldots \ldots \ldots \ldots \ldots \ldots \ldots \ldots \ldots \ldots \ldots \ldots \ldots \ldots \ldots \ldots \ldots$

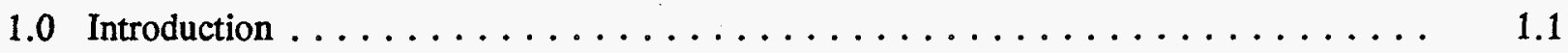

2.0. Materials and Methods $\ldots \ldots \ldots \ldots \ldots \ldots \ldots \ldots \ldots \ldots \ldots \ldots \ldots \ldots \ldots$

2.1 Placement of Area TLDs $\ldots \ldots \ldots \ldots \ldots \ldots \ldots \ldots \ldots \ldots \ldots \ldots \ldots \ldots \ldots$

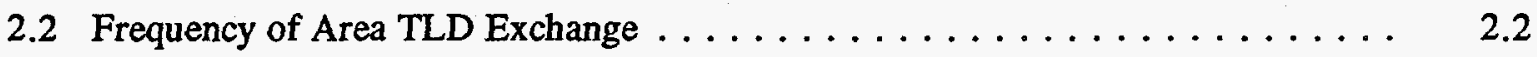

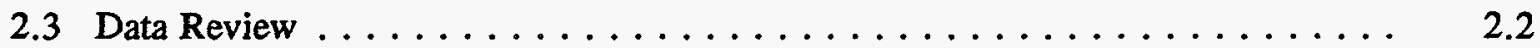

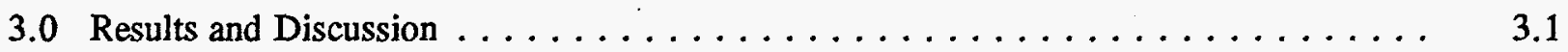

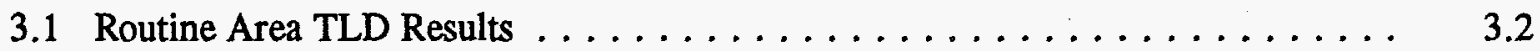

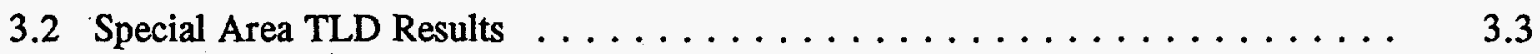

4.0 Conclusions $\ldots \ldots \ldots \ldots \ldots \ldots \ldots \ldots \ldots \ldots \ldots \ldots \ldots \ldots \ldots \ldots$

5.0 References $\ldots \ldots \ldots \ldots \ldots \ldots \ldots \ldots \ldots \ldots \ldots \ldots \ldots \ldots \ldots \ldots \ldots \ldots$

Appendix A - TLD Processing, Calibration, and Dose Assessment $\ldots \ldots \ldots \ldots$. . . . .

Appendix B - Locations of Area Monitoring TLDs . . . . . . . . . . . . . B.1

Appendix C - Area Monitoring TLD Results for CY $1993 \ldots \ldots \ldots \ldots \ldots \ldots$

Appendix D - Area Monitoring TLD Results for CY $1994 \ldots \ldots \ldots \ldots \ldots \ldots$. . . . . . . . 



\subsection{Introduction}

The Department of Energy (DOE) Radiological Control Manual (RCM)(DOE 1994), first issued in 1992, establishes practices for radiological control activities at DOE facilities. Article 514 of the RCM discusses the establishment and maintenance of a comprehensive area dosimeter monitoring program to minimize the number of areas requiring issuance of personnel dosimeters and to demonstrate that doses outside of Radiological Buffer Areas are negligible. As discussed in Article 514, area monitoring dosimeters

- shall be used to record and document radiation levels in routinely occupied areas adjacent to areas where radiation or operations with radiation exist (not applicable when the radiation arises solely from low-energy beta sources such as ${ }^{14} \mathrm{C}$ or ${ }^{3} \mathrm{H}$ )

- should be used in Radiologically Controlled Areas to supplement existing monitoring programs and to provide data in the event of an emergency

- should be used to support dosimetry investigations where personnel express concern about their work environment and exposure to ionizing radiation.

In January 1993, Pacific Northwest National Laboratory (PNNL) $)^{(a)}$ established an area monitoring thermoluminescent dosimeter (TLD) program in accordance with Article 514 of the RCM. The program was conducted as outlined by Bivins ${ }^{(b)}$ during calendar years 1993 (CY 1993) and 1994 (CY 1994). The program is now implemented according to RCP-5.1.04, "Area Monitoring TLD Program," issued in PNL-MA-26, PNL Radiological Control Implementing Procedures, in November 1995. Data from the program were also used to support the PNNL As Low As Reasonably Achievable (ALARA) program. The materials and methods used in collecting area monitoring TLD data and program results for CY 1993 and CY 1994 are presented in this report.

(a) The Pacific Northwest National Laboratory is operated for the U.S. Department of Energy by Battelle under Contract DE-AC06-76RLO 1830. Battelle also owns and operates private facilities near the Hanford Site.

(b) Bivins, S. R. February 24, 1993. Letter Report to D. P. Higby, "Area Monitoring Dosimeter." Pacific Northwest Laboratory, Richland, Washington. 



\subsection{Materials and Methods}

The Hanford Basic TLD was used as the dosimeter for this program during CY 1993 and CY 1994. The TLD was accredited by the DOE Laboratory Accreditation Program (DOELAP) and consisted of a single TLD-700 chip suspended in a plastic card made of gray Noryl ${ }^{\star}$ thermoplastic resin through the use of Tefion ${ }^{\oplus}$ films. The TLDs were read for deep dose and were corrected for naturally occurring environmental radiation. A brief description of TLD processing, calibration, and the dose algorithm used in determining doses can be found in Appendix A. A more detailed description can be found in PNL-MA-568, Hanford External Dosimetry Program Manual (October 1989 issue). PNL-MA-568 was reissued in October 1994. This revision described the area TLDs that were used in the field starting the third quarter of CY 1995.

\subsection{Placement of Area TLDs}

Area TLDs were placed in the following PNNL facilities whether DOE-owned, DOE-leased, or Battelle private:

- all 300 Area PNNL facilities where staff worked at least eight hours per month

- all PNNL facilities where staff conduct radiological work (i.e., have a current Radiological Work Permit)

- all PNNL facilities that were located within $15 \mathrm{~m}(\sim 50 \mathrm{ft})$ of another facility (including those of other Hanford Site contractors) containing a radiological area (indoors or outdoor).

TLDs positioned as discussed above are referred to as "routine" area TLDs in this report. Area TLDs were also positioned in facilities as approved by the Radiological Control organization for special situations such as ALARA evaluations. In this report, these are referred to as "special" area TLDs.

A list of routine and special area TLD locations is included as Appendix B. The number of area TLDs in each facility was determined according to the following criteria:

- at least one area TLD per facility

- one additional area TLD for every 25 staff members for facilities that require area TLDs but do not contain a Radiologically Controlled Area or a radiological area

- one additional area TLD for every 15 staff members for facilities that require area TLDs and contain a Radiologically Controlled Area or a radiological area.

- Noryl is a registered trademark of the General Electric Corporation, Selkirk, New York.

- Teflon is a registered trademark of E. I. du Pont de Nemours Co., Inc., Wilmington, Delaware. 
Additional area TLDs were positioned as determined by the Radiological Control organization.

Each area TLD was positioned facing the potential source of exposure. If the potential source of exposure was from within the facility, then the area TLD was placed on the wall opposite the potential source. If the potential source of exposure was located outside the facility, then the area TLD was placed inside of the exterior wall facing the potential source. The TLDs were placed 1 to $2 \mathrm{~m}$ ( 3 to $6 \mathrm{ft}$ ) from the floor, depending on whether staff in the area would be standing or seated.

Each area TLD was identified with an attached bar code label containing a facility ID (e.g., 337 LOC.5) and a TLD identification number beginning with the letter " $A$ " to denote an area TLD followed by a four-digit number (e.g., A3014). When placed in the facility, each TLD was sealed in a plastic bag and put in a plastic dosimeter holder.

\subsection{Frequency of Area TLD Exchange}

All area TLDs were scheduled to be exchanged and analyzed on a quarterly schedule. During CY 1994, the second quarter TLDs were left in the field through the end of the third quarter. The area monitoring TLD procedure (Bivins 1993) allows for a facility manager to request a special exchange for any TLD in his/her facility. The Radiological Control Manager may also request a special exchange for area TLDs in any facility. Any area TLD changed out was immediately replaced with another area TLD unless the area TLD location was being discontinued.

\subsection{Data Review}

Any area TLD result greater than 75 mrem in a quarter was investigated. This action level was based on ensuring that an individual would not likely receive greater than 100 mrem annually (the trigger level for requiring personnel monitoring). The investigation level of $75 \mathrm{mrem}$ per quarter was derived by dividing the 100 mrem annual limit by four and adjusting for worker occupancy. The area TLDs were exposed for approximately 8736 hours annually while individual occupancy was assumed to be 2000 hours $(8 \mathrm{~h} / \mathrm{d}, 5 \mathrm{~d} / \mathrm{wk}$, and $50 \mathrm{wk} / \mathrm{yr})$. Therefore, the occupancy-corrected quarterly limit is as follows:

Quarterly limit $=(100 \mathrm{mrem} / 4)(8760 \mathrm{~h} / 2000 \mathrm{~h})=110 \mathrm{mrem}$

The 110-mrem calculated quarterly limit was reduced to 75 mrem to allow for such factors as processing time, processing errors, the potential for individuals being present more than $2000 \mathrm{~h}$ annually, and the potential for maximum exposure rates occurring during occupancy hours. 


\subsection{Results and Discussion}

Table 3.1 summarizes area monitoring TLD results for CY 1993 and CY 1994. Quarterly area monitoring TLD results are grouped into dose ranges (i.e., $\leq 10 \mathrm{mrem} ;>10 \mathrm{mrem}$ but $<75 \mathrm{mrem}$; $\geq 75 \mathrm{mrem}$ ). None of the quarterly area monitoring TLD results for routine locations exceeded the quarterly investigation level of $75 \mathrm{mrem}$. The results support the conclusion that personnel dosimeters are not necessary for staff in the areas monitored by the area TLDs.

Table 3.1. Summary of Area Monitoring TLD Results

\begin{tabular}{|c|c|c|}
\hline & CY 1993 & CY 1994 \\
\hline \multicolumn{3}{|l|}{ Routine Area TLDs } \\
\hline - Number of Area TLD Locations & 115 & 118 \\
\hline $\begin{array}{l}\text { - Total Number of Area TLDs } \\
\text { Analyzed }\end{array}$ & $430^{(a)}$ & $354^{(b)}$ \\
\hline \multicolumn{3}{|l|}{ - Area TLD Results by Dose Range } \\
\hline$-\quad \leq 10 \mathrm{mrem}$ & 409 & 333 \\
\hline - $\quad>10$ mrem but $<75$ mrem & 21 & 21 \\
\hline$-\quad \geq 75$ mrem $^{(c)}$ & 0 & 0 \\
\hline \multicolumn{3}{|l|}{ Special Area TLDs } \\
\hline - Number of Area TLD Locations & 1 & 1 \\
\hline - Total Number of Area TLD Analyzed & 2 & 3 \\
\hline \multicolumn{3}{|l|}{ - Area TLD Results by Dose Range } \\
\hline$-\quad \leq 10$ mrem & 0 & 0 \\
\hline - $>10$ mrem but $<75$ mrem & 0 & 0 \\
\hline - $\quad \geq 75$ mrem $^{(c)}$ & 2 & 3 \\
\hline \multicolumn{3}{|c|}{$\begin{array}{l}\text { (a) The totals do not equal } 460 \text { (four times the number of TLD } \\
\text { locations) because the } 30 \text { locations outside of the } 300 \text { Area } \\
\text { were initiated in the second quarter of CY } 1993 \text {. } \\
\text { (b) The totals do not equal } 472 \text { (four times the number of TLD } \\
\text { locations) because the second quarter CY } 1994 \text { TLDs were left } \\
\text { in the field through the end of the third quarter. } \\
\text { (c) The quarterly investigation level was } 75 \text { mrem. }\end{array}$} \\
\hline
\end{tabular}


Individual area monitoring TLD results for each quarter as well as annual totals are presented in Appendix C (CY 1993) and Appendix D (CY 1994). The results in Appendices C and D are not corrected for worker occupancy. Assuming workers to be present $2000 \mathrm{~h}$ per year, results should be multiplied by 0.23 to correct for worker occupancy.

\subsection{Routine Area TLD Results}

Quarterly area monitoring TLD results for facilities located outside of the 300 Area (622R, 747A Trl, ESB, LSL-II, PSL, RTL, 1944 Saint, 2400 Stevens, and ALE) were at background levels $(0 \mathrm{mrem})$. The 21 quarterly results for each year in the " $>10 \mathrm{mrem}$ but $<75 \mathrm{mrem}$ " range from Table 3.1 were from locations in the 300 Area. Although results were less than the " 75 mrem" investigation level, a review was performed on values at the upper end of this range ( $250 \mathrm{mrem}$ ) to evaluate trends and the need for repositioning of the area TLDs. The four locations that fell into this range are discussed below (unless noted otherwise, doses are uncorrected for worker occupancy):

- TLD ID\# A3007, located in the 3718-B Building, measured exposure from the 340 Building (a Westinghouse Hanford waste storage facility). Total measured doses for CY 1993 and CY 1994 at this location were $130 \mathrm{mrem}$ and $120 \mathrm{mrem}$, respectively, with a maximum quarterly dose of $50 \mathrm{mrem}$. Workers were estimated to be in this location only $1 \%$ of their work time, and most of their work time was spent in the 3718-A Building. The area TLD located in the 3718-A Building (A3006) measured total doses of only $30 \mathrm{mrem}$ (CY 1993) and $70 \mathrm{mrem}$ (CY 1994).

- TLD ID\# A3049, located in the main entrance to the 3730 Building, measured exposure from the ${ }^{60} \mathrm{Co}$ source located in Room 2 of the 3730 Building. Total measured doses for the year at this location were 210 mrem for CY 1993 and 120 mrem for CY 1994 with a maximum quarterly dose of 70 mrem. During CY 1993 and first quarter of CY 1994, the area TLD was located in the hallway directly outside of the ${ }^{60} \mathrm{Co}$ exposure room where the workers spent a small fraction of their time. The area TLD location was repositioned the second quarter of CY 1994 to an area more representative of dose received by personnel assigned to the facility. In the new location, the total dose for the last three quarters of CY 1994 was only 40 mrem.

- TLD ID\# A3070, located in the 327 Building front office, measured exposure from the canyon area. Total measured doses for CY 1993 and CY 1994 were 70 mrem and $130 \mathrm{mrem}$, respectively. The area TLD for the first quarter of CY $1994 \mathrm{had}$ a reading of $50 \mathrm{mrem}$. Since clerical staff occupied this room full-time during their work day (i.e., $\sim 2000 \mathrm{~h} / \mathrm{yr}$ ), the recommendation was made to make this location a Radiological Buffer Area. This would require any occupants to wear personnel dosimeters.

- TLD ID\# A3074 was located in the north-south hallway outside Room 2 of the 329 Building. Total measured doses for CY 1993 and CY 1994 were $30 \mathrm{mrem}$ and $120 \mathrm{mrem}$, respectively. During CY 1993, modifications were made to laboratories adjacent to the area TLD location. Modifications, completed in early CY 1994, established a radioactive material storage area in Room 2. This storage area was the cause of the increased TLD readings in CY 1994. A recommendation was made to relocate the radioactive material storage area. 


\subsection{Special Area TLD Results}

One special area TLD location was used during CY 1993 and CY 1994. This area TLD was located in Room 504 of the 325 Building and referred to as A3112 during CY 1993 and A3104 during CY 1994. Room 504 is located within the Radiological Buffer Area of the 325 Building. Facility management requested the area TLD in order to evaluate the cause of an elevated personnel dosimeter reading for a worker who had an office in the room. Total measured dose for the last three quarters of CY 1993 was 830 mrem and for the entire CY 1994 was 930 mrem. Corrected for worker occupancy (2000 h/yr), a worker could have received approximately $190 \mathrm{mrem}$ (CY 1993) and $215 \mathrm{mrem}$

(CY 1994). Based on the area TLD results, the worker's office was moved out of Room 504. 



\subsection{Conclusions}

The area monitoring TLD program for CY 1993 and CY 1994 was a useful tool in determining exposure trends in work areas located outside radiological areas. In several situations, the information obtained from this program was used to relocate staff or radioactive material, resulting in potential does reductions for staff.

All routine area monitoring TLD results were less than 50 mrem annually after correcting for worker occupancy. The results support the conclusion that personnel dosimeters are not necessary for staff in these monitored areas. 
- 


\subsection{References}

U.S. Department of Energy (DOE). 1994. Radiological Control Manual. DOE/EH-0256T, Rev. 1, Washington, D.C. 

Appendix A

TLD Processing, Calibration, and Dose Assessment 



\section{Appendix A}

\section{TLD Processing, Calibration, and Dose Assessment}

\section{Processing}

Area TLDs were annealed at $80^{\circ} \mathrm{C}$ for 16 hours before being issued to improve long-term consistency between TLDs. They were cleaned in two ultrasonic cleaning baths before processing to remove oils and mineral deposits that might affect the readout process. After cleaning, TLDs were annealed for 30 minutes at $80^{\circ} \mathrm{C}$ to ensure that they were dry and to volatize any residues.

Area TLD processing (readout) was done using the Hanford automated reader system. The system heater was maintained at $\sim 300^{\circ} \mathrm{C}$. Glow curves were recorded for all TLDs processed.

\section{Calibration}

Area TLDs were calibrated using sources that were traceable to the National Institute of Standards and Technology (NIST). The primary calibration was the deep dose from an onphantom ${ }^{137} \mathrm{Cs}$ exposure.

\section{Dose Assessment}

The contribution to the area TLD from naturally occurring environmental radiation was determined using the following equation:

$$
\text { ENV.FAC }=\frac{0.18\left(1-\mathrm{e}^{-[0.00078(\mathrm{Y})]}\right)}{0.00078}
$$

$$
\begin{aligned}
& \text { where ENV.FAC } \begin{aligned}
= & \begin{array}{l}
\text { environmental dose based on the number of days elapsed } \\
\text { between previous and current dosimeter processing }
\end{array} \\
0.18 & =\begin{array}{l}
\text { the expected dose in mrem/day from environmental radiation } \\
\text { in the Hanford environs }
\end{array}
\end{aligned}
\end{aligned}
$$

\section{A.1}




$$
\begin{aligned}
& \mathrm{Y} 1= \text { the number of days between the previous and current TLD } \\
& \text { processing }
\end{aligned}
$$

The deep dose for area TLDs was calculated as follows:

$$
\text { Dose }=\frac{\mathrm{C}_{\mathrm{o}} *(\mathrm{R}-2 \mathrm{TA}) * \mathrm{RSF} * \mathrm{CSF}}{\mathrm{PSF}}-\mathrm{ENV} \cdot \mathrm{FAC}
$$

where

$$
\begin{aligned}
& \mathrm{C}_{\mathrm{o}}=\text { the conversion factor for converting chip response to mrem for } \\
& \text { area TLD } \\
& \mathrm{R}=\text { raw chip count before any adjustments } \\
& 2 \mathrm{TA}=\text { the average for the basic background control dosimeters } \\
& \mathrm{RSF}=\text { the reader sensitivity factor } \\
& \mathrm{CSF}=\text { the chip sensitivity factor for position } 1 \text { for the reader } \\
& \text { PSF }=\text { the position sensitivity factor for position } 1 \text { for the reader } \\
& \text { ENV.FAC }=\text { environmental dose based on the number of days elapsed between }
\end{aligned}
$$

For the area TLDs, the shallow dose is set equal to the deep dose. 


\section{Appendix B}

Locations of Area Monitoring TLDs 



\section{Appendix B}

\section{Locations of Area Monitoring TLDs}

\begin{tabular}{|c|c|c|c|}
\hline TOB ID \# & BYOO & Socation & Description of t rocation. \\
\hline - & & $\begin{array}{l}\text { Routine } \\
\text { TLDs }\end{array}$ & \\
\hline A-3000 & 303-J & LOC 1 & Lunch room, west wall, bulletin board \\
\hline A-3001 & 305-B & LOC. 1 & Main entrance, hallway, bulletin board \\
\hline A-3002 & 3760 & TRL. 1 & Bulletin board, corridor \\
\hline A-3003 & 3760 & TRL. 3 & Bulletin board, corridor \\
\hline A-3004 & 350 & LOC. 1 & Bulletin board in copy area \\
\hline A-3005 & 350 & LOC. 2 & Inside Room 156 \\
\hline A-3006 & 3718-A & LOC. 1 & Main office \\
\hline A-3007 & 3718-B & LOC 1 & Above phone on north wall \\
\hline A-3008 & 3731-A & LOC. 1 & Bulletin board in lunchroom \\
\hline A-3009 & 3760 & LOC. 1 & Lobby \\
\hline A-3010 & 3760 & LOC. 2 & Second floor corridor on bulletin board \\
\hline A-3011 & 3760 & LOC. 3 & Second floor - copying room \\
\hline A-3012 & 3762 & LOC. 1 & First floor near fire extinguisher sign \\
\hline A-3013 & 3762 & LOC. 2 & Second floor in copy room \\
\hline A-3014 & 3762 & LOC. 3 & Bulletin board in Room 214 \\
\hline A-3015 & 3764 & LOC. 1 & Main entrance - bulletin board in corridor \\
\hline A-3016 & 3764 & LOC. 2 & Second floor - bulletin board at top of stairs \\
\hline A-3017 & 306-W & TRL. 2 & South end, bulletin board \\
\hline A-3018 & 306-W & TRL. 4 & South end, bulletin board \\
\hline A-3019 & $306-W$ & TRL. 5 & South end, bulletin board \\
\hline A-3020 & 306-W & TRL. 6 & West hallway \\
\hline A-3021 & 318 & TRL. 2 & Main entrance, bulletin board, corridor \\
\hline A-3022 & 318 & TRL. 4 & Bulletin board on the north wall (main entrance) \\
\hline A-3023 & 318 & TRL. 5 & Bulletin board \\
\hline A-3024 & 320 & NE TRL & South door \\
\hline A-3025 & 320 & SE TRL & Northwest bulletin board (Westinghouse) \\
\hline A-3026 & 324 & TRL. 1 & Bulletin board in corridor \\
\hline
\end{tabular}

B.1 


\begin{tabular}{|c|c|c|c|}
\hline TLD ID \# & BLDG & $\begin{array}{c}\text { Location } \\
\text { ID \# }\end{array}$ & Description of Location \\
\hline A-3027 & 324 & TRL. 2 & Bulletin board in corridor \\
\hline A-3028 & 326 & TRL. 1 & Bulletin board, center corridor \\
\hline A-3029 & 326 & TRL. 2 & Bulletin board, center corridor \\
\hline A-3030 & 329 & TRL. 1 & Southwest entrance - north wall \\
\hline A-3031 & 329 & TRL. 2 & Inside of Room 2 \\
\hline A-3032 & 3765 & TRL. 1 & Bulletin board in main entrance \\
\hline A-3033 & 3765 & TRL. 2 & Main entrance - bulletin board in corridor \\
\hline A-3034 & $306-W$ & LOC. 1 & Main entrance on first bulletin board \\
\hline A-3035 & $306-W$ & LOC. 2 & Second fioor - bulletin board in Room 223 \\
\hline A-3036 & $306-W$ & LOC. 3 & Second floor - bulletin board near copy machine \\
\hline A-3037 & 314 & LOC. 1 & Hallway near rear entrance across from Room 5 \\
\hline A-3038 & 314 & LOC. 2 & East-west hallway across from Room 17 \\
\hline A-3039 & 318 & LOC. 1 & Front lobby \\
\hline A-3040 & 318 & LOC. 2 & Main corridor of second floor \\
\hline A-3041 & 318 & LOC. 3 & Main corridor outside instrument receiving \\
\hline A-3042 & 320 & LOC. 1 & Lobby \\
\hline A-3043 & 320 & LOC. 2 & Down west stairs through south door - Room B62 \\
\hline A-3044 & 331 & LOC. 1 & First floor lobby on east wall \\
\hline A-3045 & 331 & LOC. 2 & Second floor hallway on bulletin board outside of Room 25 \\
\hline A-3046 & 331 & LOC. 3 & Third floor hallway on bulletin board outside of Room 66 \\
\hline A-3047 & 3720 & LOC. 1 & North and south corridor across from Room 221 \\
\hline A-3048 & 3720 & LOC. 2 & Bulletin board in lunchroom \\
\hline A-3049 & 3730 & LOC. 1 & Main entrance, bulletin board, east wall \\
\hline A-3050 & 3745 & LOC. 1 & Counting Laboratory bulletin board \\
\hline A-3051 & $3745-A$ & LOC. 1 & Bulletin board on west wall \\
\hline A-3052 & 3745-B & LOC. 1 & Bulletin board in main entrance \\
\hline A-3053 & 3746 & LOC. 1 & Last office on left as one enters (Room 3) \\
\hline A-3054 & 3746-A & LOC. 1 & Main corridor outside of Room 14 \\
\hline A-3055 & 3708 & LOC. 1 & Corridor \\
\hline A-3056 & 324 & LOC. 1 & Bulletin board outside of lunchroom \\
\hline A-3057 & 324 & LOC. 2 & Second floor, in corridor outside of Room 218 \\
\hline A-3058 & 324 & LOC. 3 & Second floor, in corridor outside of Room 208 \\
\hline A-3059 & 324 & LOC. 4 & Second floor, inside of Room 279 \\
\hline A-3060 & 324 & LOC. 5 & Inside Room 185 \\
\hline A-3061 & 325 & LOC. 1 & Main lobby near north door \\
\hline A-3062 & 325 & LOC. 2 & Mezzanine, Room 5, pipe above north door \\
\hline
\end{tabular}




\begin{tabular}{|c|c|c|c|}
\hline T110 $1 \mathrm{D} \#$ & $\mathrm{BLDO}$ & Uocation & Bescription of Socation \\
\hline A-3063 & 325 & LOC. 3 & Second floor by elevator \\
\hline A-3064 & 326 & LOC. 1 & Lobby \\
\hline A-3065 & 326 & LOC. 2 & First floor - in front of exit door to basement \\
\hline A-3066 & 326 & LOC. 3 & First floor - in corridor across from Room 48-B \\
\hline A-3067 & 326 & LOC. 4 & Second fioor - lunchroom bulletin board \\
\hline A-3068 & 326 & LOC. 5 & Second floor - corridor near Room 40-C \\
\hline A-3069 & 327 & LOC. 1 & Lobby \\
\hline A-3070 & 327 & LOC. 2 & Secretary's office \\
\hline A-3071 & 329 & LOC. 1 & Lobby \\
\hline A-3072 & 329 & LOC. 2 & Electrician's office \\
\hline \multirow[t]{2}{*}{ A-3073 } & 329 (CY 93) & LOC. 3 & Northwest hallway bulletin board \\
\hline & 336-1 (CY 94) & LOC. 1 & New lobby near fire alarm \\
\hline A-3074 & 329 & LOC. 4 & North-south hallway (Room 2) \\
\hline A-3075 & 329 & LOC. 5 & North-south hallway (Room 5C-1) \\
\hline A-3076 & 3760 & TRL. 2 & Bulletin board - corridor \\
\hline A-3077 & 329 & TRL. 4 & Bulletin board - corridor \\
\hline A-3078 & 329 & TRL. 5 & Bulletin board - corridor \\
\hline A-3079 & 329 & TRL. 6 & Bulletin board - corridor \\
\hline A-3080 & 337 & LOC. 1 & First floor (basement) - south \\
\hline A-3081 & 337 & LOC. 2 & First floor (basement) - north \\
\hline A-3082 & 337 & LOC. 3 & Second floor (south) above drinking fountain \\
\hline A-3083 & 337 & LOC. 4 & Second floor (north) above drinking fountain \\
\hline A-3084 & 337 & LOC. 5 & Third floor (south) on picture board \\
\hline A-3085 & 337 & LOC. 6 & Third floor (north) above drinking fountain \\
\hline A-3086 & 622-R & LOC. 1 & Corridor by weather station room \\
\hline A-3087 & 622-R & LOC. 2 & Exit sign in front of men's room \\
\hline A-3088 & $747-A$ & LOC. 1 & Bulletin board on west wall by scale \\
\hline A-3089 & $747-A$ & $\begin{array}{l}\text { TRL. } 1 \text {, } \\
\text { LOC. } 1\end{array}$ & Bulletin board by south door \\
\hline A-3090 & $747-A$ & $\begin{array}{l}\text { TRL. } 1 \text {, } \\
\text { LOC. }\end{array}$ & South door bulletin board \\
\hline A-3091. & ESB & LOC. 1 & Inside of Room 14 \\
\hline A-3092 & ESB & LOC. 2 & Entry way to Room 31 \\
\hline A-30993 & LSL-II & LOC. 1 & Lunchroom \\
\hline A-3094 & LSL-II & LOC. 2 & Corridor outside of Lab 1404 \\
\hline A-3095 & LSL-II & LOC. 3 & Lab 1508 \\
\hline
\end{tabular}

B. 3 


\begin{tabular}{|c|c|c|c|}
\hline $\mathrm{THD} \mathrm{ID}$ \% & BHDG & Uocation & Bescription of location. \\
\hline A-3096 & LSL-II & LOC. 4 & Lab 1419 \\
\hline A-3097 & LSL-II & LOC. 5 & Office 1224 \\
\hline A-3098 & LSL-II & LOC. 6 & Lab 1335 \\
\hline A-3099 & PSL & LOC. 1 & Bulletin board in Lab 1607 \\
\hline$A-3100$ & PSL & LOC. 2 & Bulletin board in Lab 1508 \\
\hline A-3101 & PSL & LOC. 3 & East entrance on secretary's desk \\
\hline A-3102 & PSL & LOC. 4 & Bulletin board in Lab 1304 \\
\hline A-3103 & PSL & LOC. 5 & Corridor outside of Lab 315 \\
\hline A-3105 & RTL & LOC. 1 & Lab 428 \\
\hline A-3106 & RTL & LOC. 2 & Lab 328 \\
\hline A-3107 & RTL & LOC. 3 & Lab 218 \\
\hline$A-3108$ & RTL & LOC. 4 & Outside of Lab 132 \\
\hline A-3109 & RTL & LOC. 5 & Canteen above fire extinguisher \\
\hline A-3110 & RTL & LOC. 6 & Bulletin board in Room 21-A \\
\hline A-3111 & SAINT & LOC. 1 & High-bay near analytical scale \\
\hline A-3113 & 2400. & LOC. 1 & Secretary's desk located in main entrance \\
\hline A-3114 & 2400 & LOC. 2 & Bulletin board in entry way to Room 1414 \\
\hline A-3115 & 2400 & LOC. 3 & High-bay bulletin board in entry to Lab 1445 \\
\hline A-3116 & 2400 & LOC. 4 & Second floor on bulletin board outside of Room 2428 \\
\hline A-3117 & ALE & LOC. 1 & Room 109 \\
\hline A-3118 & ALE & LOC. 2 & Lunchroom \\
\hline A-3119 & $3718-G$ & LOC. 1 & North wall of warehouse office \\
\hline & & Special & \\
\hline$A-3112$ (CY 93) & \multirow[t]{2}{*}{325} & \multirow[t]{2}{*}{ LOC. 4} & \multirow[t]{2}{*}{ Room 504} \\
\hline A-3014 (CY 94) & & & \\
\hline
\end{tabular}

B. 4 


\section{Appendix C}

Area Monitoring TLD Results for CY 1993 



\section{Appendix C}

\section{Area Monitoring TLD Results for CY $1993^{(a)}$}

\begin{tabular}{|c|c|c|c|c|c|c|}
\hline \multicolumn{2}{|c|}{ 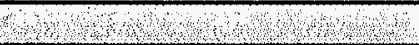 } & \multirow{2}{*}{$\begin{array}{c}\text { 1st Quarter } \\
\text { Deep Dose (mrem) }\end{array}$} & \multirow{2}{*}{$\begin{array}{l}\text { 2nd Quarter } \\
\text { Deep Dose (mrem) }\end{array}$} & \multirow{2}{*}{$\begin{array}{l}\text { 3rd Quarter } \\
\text { Deep Dose (mrem) }\end{array}$} & \multirow{2}{*}{$\begin{array}{l}\text { 4th Quarter } \\
\text { Deep Dose (mrem) }\end{array}$} & \multirow{2}{*}{$\begin{array}{l}\text { Annual } \\
\text { Deep Dose (mrem) }\end{array}$} \\
\hline TLD ID\# & TLD Location & & & & & \\
\hline & & \multicolumn{5}{|c|}{ RoutineArea TLDs } \\
\hline A3000 & 303J LOC.1 & 40 & 0 & 0 & 0 & 40 \\
\hline A3001 & 305B LOC.1 & 30 & 0 & 0 & 0 & 30 \\
\hline $\mathrm{A} 3002$ & 3760 TRL. 1 & 10 & 0 & 0 & 0 & 10 \\
\hline $\mathrm{A} 3003$ & 3760 TRL. 3 & 10 & 0 & 0 & 0 & 10 \\
\hline $\mathrm{A3004}$ & 350 LOC. 1 & 10 & 0 & 0 & 0 & 10 \\
\hline $\mathrm{A} 3005$ & 350 LOC. 2 & 0 & 0 & 0 & 0 & 0 \\
\hline A3006 & 3718A LOC.1 & 20 & 10 & 0 & 0 & 30 \\
\hline A3007 & 3718B LOC. 1 & 50 & 30 & 30 & 20 & 130 \\
\hline A3008 & 3731 A LOC. 1 & 10 & 0 & 0 & 0 & 10 \\
\hline A3009 & 3760 LOC. 1 & 0 & 0 & 0 & 0 & 0 \\
\hline A3010 & 3760 LOC. 2 & 0 & 0 & 0 & 0 & 0 \\
\hline A3011 & 3760 LOC. 3 & 0 & 0 & 0 & 0 & 0 \\
\hline A3012 & 3762 LOC. 1 & 0 & 0 & 0 & 0 & 0 \\
\hline A3013 & 3762 LOC. 2 & 20 & 10 & 0 & 0 & 30 \\
\hline A3014 & 3762 LOC. 3 & 20 & 20 & 0 & 20 & 60 \\
\hline A3015 & 3764 LOC. 1 & 0 & 0 & 0 & 0 & 0 \\
\hline A3016 & 3764 LOC. 2 & 0 & 0 & 0 & 0 & 0 \\
\hline A3017 & $306 \mathrm{~W}$ TRL.2 & 10 & 0 & 0 & 0 & 10 \\
\hline A3018 & $306 \mathrm{~W}$ TRL. 4 & 10 & 0 & 0 & 0 & 10 \\
\hline A3019 & $306 W$ TRL. 5 & 20 & 10 & 10 & 0 & 40 \\
\hline A3020 & 306W TRL.6 & 10 & 0 & 0 & 0 & 10 \\
\hline A3021 & 318 TRL.2 & 0 & 0 & 0 & 0 & 0 \\
\hline A3022 & 318 TRL.4 & 0 & 0 & 0 & 0 & 0 \\
\hline A3023 & 318 TRL. 5 & 10 & 0 & 0 & 0 & 10 \\
\hline A3024 & 320 NE.TRL & 0 & 0 & 0 & 0 & 0 \\
\hline A3025 & 320 SE.TRL & 0 & 0 & 0 & 0 & 0 \\
\hline A3026 & 324 TRL. 1 & 0 & 0 & 0 & 0 & 0 \\
\hline A3027 & 324 TRL.2 & 0 & 0 & 0 & 0 & 0 . \\
\hline A3028 & 326 TRL. 1 & 20 & 0 & 0 & 0 & 20 \\
\hline A3029 & 326 TRL.2 & 0 & 0 & 0 & 0 & 0 \\
\hline A3030 & 329 TRL. 1 & 0 & 0 & 0 & 0 & 0 \\
\hline A3031 & 329 TRL. 2 & 0 & 0 & 0 & 0 & 0 \\
\hline A3032 & 3765 TRL. 1 & 0 & 0 & 0 & 0 & 0 \\
\hline A3033 & 3765 TRL.2 & 10 & 0 & 0 & 0 & 10 \\
\hline
\end{tabular}


Appendix C

Area Monitoring TLD Results for CY $1993^{(a)}$

\begin{tabular}{|c|c|c|c|c|c|c|}
\hline \multicolumn{2}{|c|}{ 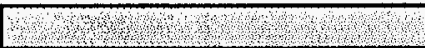 } & \multirow{2}{*}{$\begin{array}{c}\text { Ist Quarter } \\
\text { Deep Dose (mrem) }\end{array}$} & \multirow{2}{*}{$\begin{array}{c}\text { 2nd Quarter } \\
\text { Deep Dose (mrem) }\end{array}$} & \multirow{2}{*}{$\begin{array}{l}\text { 3rd Quarter } \\
\text { Deep Dose (mrem) }\end{array}$} & \multirow{2}{*}{\begin{tabular}{|c|} 
4th Quarter \\
Deep Dose (mrem)
\end{tabular}} & \multirow{2}{*}{$\begin{array}{l}\text { Annual } \\
\text { Deep Dose (mrem) }\end{array}$} \\
\hline TLD ID\# & TLD Location & & & & & \\
\hline A3034 & 306 W LOC. 1 & 10 & 0 & 0 & $\begin{array}{c}0 \\
\end{array}$ & 10 \\
\hline $\mathrm{A} 3035$ & 306 W LOC. 2 & 10 & 0 & 0 & 0 & 10 \\
\hline A3036 & 306W LOC. 3 & 10 & 0 & 0 & 0 & 10 \\
\hline A3037 & 314 LOC.1 & 10 & 0 & 0 & 0 & 10 \\
\hline $\mathrm{A} 3038$ & 314 LOC. 2 & 10 & 0 & 0 & 0 & 10 \\
\hline A3039 & 318 LOC. 1 & 0 & 0 & 0 & 0 & 0 \\
\hline A3040 & 318 LOC. 2 & 0 & 0 & 0 & 0 & 0 \\
\hline A3041 & 318 LOC. 3 & 0 & 0 & 0 & 0 & 0 \\
\hline $\mathrm{A} 3042$ & 320 LOC. 1 & 0 & 0 & 0 & 0 & 0 \\
\hline $\mathrm{A} 3043$ & 320 LOC. 2 & 10 & 0 & 0 & 0 & 10 \\
\hline A3044 & 331 LOC. 1 & 0 & 0 & 0 & 0 & 0 \\
\hline A3045 & 331 LOC. 2 & 0 & 0 & 0 & 0 & 0 \\
\hline A3046 & 331 LOC. 3 & 0 & 0 & 0 & 0 & 0 \\
\hline A3047 & 3720 LOC. 1 & 0 & 0 & 0 & 0 & 0 \\
\hline A3048 & 3720 LOC. 2 & 0 & 0 & 0 & 30 & 30 \\
\hline A3049 & 3730 LOC. 1 & 50 & 40 & 60 & 60 & 210 \\
\hline A3050 & 3745 LOC. 1 & 0 & 0 & 0 & 0 & 0 \\
\hline A3051 & $3745 A$ LOC. 1 & 10 & 0 & 0 & 0 & 10 \\
\hline A3052 & 3745B LOC. 1 & 0 & 0 & 0 & 0 & 0 \\
\hline A3053 & 3746 LOC. 1 & 0 & 0 & 0 & 0 & 0 \\
\hline A3054 & 3746 A LOC. 1 & 10 & 0 & 0 & 0 & 10 \\
\hline A3055 & 3708 LOC. 1 & 10 & 0 & 0 & 0 & 10 \\
\hline A3056 & 324 LOC. 1 & 0 & 0 & 0 & 0 & 0 \\
\hline A3057 & 324 LOC. 2 & 0 & 0 & 0 & 0 & 0 \\
\hline A3058 & 324 LOC. 3 & 10 & 0 & 0 & 0 & 10 \\
\hline A3059 & 324 LOC. 4 & 0 & 0 & 0 & 0 & 0 \\
\hline A3060 & 324 LOC. 5 & 0 & 0 & 0 & 0 & 0 \\
\hline A3061 & 325 LOC. 1 & 0 & 0 & 0 & 0 & 0 \\
\hline A3062 & 325 LOC. 2 & 10 & 0 & 10 & 10 & 30 \\
\hline A3063 & 325 LOC. 3 & 0 & 0 & 0 & 0 & 0 \\
\hline A3064 & 326 LOC. 1 & 10 & 0 & 0 & 0 & 10 \\
\hline A3065 & 326 LOC. 2 & 10 & 0 & 0 & 0 & 10 \\
\hline A3066 & 326 LOC. 3 & 0 & 0 & 0 & 0 & 0 \\
\hline A3068 & 326 LOC. 5 & 0 & 0 & 0 & 0 & 0 \\
\hline A3069 & 327 LOC. 1 & 10 & 0 & 0 & 0 & 10 \\
\hline
\end{tabular}




\section{Appendix C}

Area Monitoring TLD Results for CY $1993^{(a)}$

\begin{tabular}{|c|c|c|c|c|c|c|}
\hline P18 & (1) & 1st Quarter & 2nd Quarter & 3rd Quarter & 4th Quarter & यैAnnual \\
\hline TLD ID\# & TLD Location & Deep Dose (mrem) & Deep Dose (mrem) & Deep Dose (mrem) & Deep Dose (mrem) & Deep Dose (mrem) \\
\hline $\mathrm{A} 3070$ & 327 LOC. 2 & 30 & 10 & 0 & 30 & 70 \\
\hline A3071 & 329 LOC. 1 & 0 & 0 & 0 & 0 & 0 \\
\hline A3072 & 329 LOC. 2 & 0 & 0 & 0 & $\overline{0}$ & 0 \\
\hline A3073 & 329 LOC. 3 & 10 & 0 & 0 & 0 & 10 \\
\hline A3074 & 329 LOC. 4 & 10 & 0 & 0 & 20 & 30 \\
\hline A3075 & 329 LOC. 5 & 0 & 0 & 0 & 0 & 0 \\
\hline A3076 & 3760 TRL. 2 & 0 & 0 & 0 & 0 & 0 \\
\hline A3077 & 329 TRL.4 & 0 & 0 & 0 & 0 & 0 \\
\hline A3078 & 329 TRL. 5 & 0 & 0 & 0 & 0 & 0 \\
\hline A3079 & 329 TRL. 6 & 0 & 0 & 0 & 0 & 0 \\
\hline A3080 & 337 LOC. 1 & 10 & 0 & 0 & 0 & 10 \\
\hline A3081 & 337 LOC. 2 & 10 & 0 & 0 & 0 & 10 \\
\hline A3082 & 337 LOC. 3 & 10 & 0 & 0 & 0 & 10 \\
\hline A3083 & 337 LOC. 4 & 10 & 0 & 0 & 0 & 10 \\
\hline A3084 & 337 LOC. 5 & 10 & 0 & 0 & 0 & 10 \\
\hline A3085 & 337 LOC. 6 & 10 & 0 & 0 & 0 & 10 \\
\hline A3086 & 622R LOC. 1 & (b) & 0 & 0 & 0 & 0 \\
\hline A3087 & 622R LOC. 2 & (b) & 0 & 0 & 0 & 0 \\
\hline A3088 & 747A LOC. 1 & (b) & 0 & 0 & 0 & 0 \\
\hline A3089 & 747A TrI LOC.1 & (b) & 0 & 0 & 0 & 0 \\
\hline A3090 & 747A Trl LOC.2 & (b) & 0 & 0 & 0 & 0 \\
\hline A3091 & ESB LOC.1 & (b) & 0 & 0 & 0 & 0 \\
\hline A3092 & ESB LOC. 2 & (b) & 0 & 0 & 0 & 0 \\
\hline A3093 & LSL-\| LOC. 1 & (b) & 0 & 0 & 0 & 0 \\
\hline A3094 & LSL-II LOC.2 & (b) & 0 & 0 & 0 & 0 \\
\hline A3095 & LSL-II LOC.3 & (b) & 0 & 0 & 0 & 0 \\
\hline A3096 & LSL-\| LOC.4 & (b) & 0 & 0 & 0 & 0 \\
\hline A3097 & LSL-1/ LOC.5 & (b) & 0 & 0 & 0 & 0 \\
\hline A3098 & LSL-1/ LOC. 6 & (b) & 0 & 0 & 0 & 0 \\
\hline A3099 & PSL LOC.1 & (b) & 0 & 0 & 0 & 0 \\
\hline A3100 & PSL LOC.2 & (b) & 0 & 0 & 0 & 0 \\
\hline A3101 & PSL LOC. 3 & (b) & 0 & 0 & 0 & 0 \\
\hline A3102 & PSL LOC.4 & (b) & 0 & 0 & 0 & 0 \\
\hline A3103 & PSL LOC. 5 & (b) & 0 & 0 & 0 & 0 \\
\hline$A 3105$ & RTL LOC. 1 & (b) & 0 & 0 & 0 & 0 \\
\hline
\end{tabular}




\section{Appendix C}

Area Monitoring TLD Results for CY $1993^{(a)}$

\begin{tabular}{|c|c|c|c|c|c|c|}
\hline \multicolumn{2}{|c|}{ 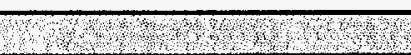 } & 1st Quarter & 2nd Quarter & 3rd Quarter & 4th Quarter & Annual \\
\hline TLD ID\# & TLD Location & Deep Dose (mrem) & Deep Dose (mrem) & Deep Dose (mrem) & Deep Dose (mrem) & Deep Dose (mrem) \\
\hline A3106 & RTL LOC. 2 & (b) & 0 & 0 & 0 & 0 \\
\hline A3107 & RTL LOC.3 & (b) & 0 & 0 & 0 & 0 \\
\hline A3108 & RTL LOC.4 & (b) & 0 & 0 & 0 & 0 \\
\hline A3109 & RTL LOC.5 & (b) & 0 & 0 & 0 & 0 \\
\hline A3110 & RTL LOC.6 & (b) & 0 & 0 & 0 & 0 \\
\hline A3111 & Saint LOC.1 & (b) & 0 & 0 & 0 & 0 \\
\hline A3113 & 2400 LOC.1 & (b) & 0 & 0 & $\overline{0}$ & 0 \\
\hline A3114 & 2400 LOC. 2 & (b) & 0 & 0 & 0 & 0 \\
\hline A3115 & 2400 LOC. 3 & (b) & 0 & 0 & 0 & 0 \\
\hline A3116 & 2400 LOC. 4 & (b) & 0 & 0 & 0 & 0 \\
\hline & & & & Special Area TLDs & & \\
\hline$A 3112^{(\mathrm{C})}$ & 325 LOC. 4 & (d) & (d) & 340 & 490 & 830 \\
\hline (a) Multi & y area TLD resu & ts by 0.23 to obtain d & se estimate corrected & for worker occupanc & & \\
\hline (b) Not ir & tiated until secol & d quarter of CY 1993 & & & & \\
\hline (c) Durin & CY 1994, the at & ea TLD at 325 LOC. & was designated as $A 3$ & 3104. & & \\
\hline (d) Not ir & tiated until third & uarter of CY 1993. & & & & \\
\hline
\end{tabular}


Appendix D

Area Monitoring TLD Results for CY 1994 



\section{Appendix D}

Area Monitoring TLD Results for CY $1994^{(a)}$

\begin{tabular}{|c|c|c|c|c|c|}
\hline & & 1st Quarter & 2nd/3rd Quarters & 4th Quarters & Annual \\
\hline TLD ID\# & TLD Location & Deep Dose (mrem) & Deep Dose (mrem) & Deep Dose (mrem) & Deep Dose (mrem) \\
\hline & & \multicolumn{4}{|c|}{ Routine Area TLDs } \\
\hline$A 3000$ & $303 \mathrm{~J}$ LOC. 1 & 0 & 0 & 0 & 0 \\
\hline A3001 & 305B LOC. 1 & 0 & 0 & 0 & 0 \\
\hline A3002 & 3760 TRL. 1 & 0 & 0 & 0 & 0 \\
\hline A3003 & 3760 TRL. 3 & 0 & 0 & 0 & 0 \\
\hline A3004 & 350 LOC. 1 & 0 & 0 & 0 & 0 \\
\hline A3005 & 350 LOC. 2 & 0 & 0 & 0 & 0 \\
\hline A3006 & 3718A LOC.1 & 20 & 30 & 20 & 70 \\
\hline $\mathrm{A} 3007$ & 3718B LOC. 1 & 40 & 50 & 30 & 120 \\
\hline A3008 & 3731A LOC.1 & (b) & 40 & 0 & 40 \\
\hline A3009 & 3760 LOC. 1 & 0 & 0 & 0 & 0 \\
\hline $\mathrm{A} 3010$ & 3760 LOC. 2 & 0 & 0 & 0 & 0 \\
\hline A3011 & 3760 LOC. 3 & 0 & 0 & 0 & 0 \\
\hline A3012 & 3762 LOC. 1 & 0 & 0 & 0 & 0 \\
\hline A3013 & 3762 LOC. 2 & 0 & 0 & 0 & 0 \\
\hline A3014 & 3762 LOC. 3 & 20 & 20 & 0 & 40 \\
\hline A3015 & 3764 LOC. 1 & 0 & 0 & 0 & 0 \\
\hline A3016 & 3764 LOC. 2 & 0 & 0 & 0 & 0 \\
\hline A3017 & 306W TRL.2 & 0 & 0 & 0 & 0 \\
\hline A3018 & $306 \mathrm{~W}$ TRL. 4 & 0 & 0 & 0 & 0 \\
\hline A3019 & $306 \mathrm{~W}$ TRL. 5 & 0 & 0 & 0 & 0 \\
\hline A3020 & 306W TRL.6 & 0 & 0 & 0 & 0 \\
\hline A3021 & 318 TRL. 2 & 0 & 0 & 0 & 0 \\
\hline A3022 & 318 TRL.4 & 0 & 0 & 0 & 0 \\
\hline A3023 & 318 TRL. 5 & 0 & 0 & 0 & 0 \\
\hline A3024 & 320 NE.TRL & 0 & 0 & 0 & 0 \\
\hline A3025 & 320 SE.TRL & 0 & 0 & 0 & 0 \\
\hline A3026 & 324 TRL. 1 & 0 & 0 & 0 & 0 \\
\hline A3027 & 324 TRL.2 & 0 & 0 & 0 & 0 \\
\hline A3028 & 326. TRL. 1 & 0 & 0 & 0 & 0 \\
\hline A3029 & 326 TRL. 2 & 0 & 0 & 0 & 0 \\
\hline A3030 & 329 TRL. 1 & 0 & 0 & 0 & 0 \\
\hline A3031 & 329 TRL. 2 & 0 & 0 & 0 & 0 \\
\hline A3032 & 3765 TRL. 1 & 0 & 0 & 0 & 0 \\
\hline
\end{tabular}




\section{Appendix D}

Area Monitoring TLD Results for CY $1994^{(a)}$

\begin{tabular}{|c|c|c|c|c|c|}
\hline & & 1st Quarter & 2nd/3rd Quarters & 4th Quarters & Annual \\
\hline TLD ID\# & TLD Location & Deep Dose (mrem) & Deep Dose (mrem) & Deep Dose (mrem) & Deep Dose (mrem) \\
\hline A3033 & 3765 TRL.2 & 0 & 0 & 0 & 0 \\
\hline A3034 & 306W LOC. 1 & 0 & 0 & 0 & 0 \\
\hline $\mathrm{A3035}$ & 306 W LOC. 2 & 0 & 0 & 0 & 0 \\
\hline A3036 & 306W LOC.3 & 0 & 0 & 0 & 0 \\
\hline A3037 & 314 LOC. 1 & 0 & 0 & 0 & 0 \\
\hline A3038 & 314 LOC. 2 & 0 & 0 & 0 & 0 \\
\hline A3039 & 318 LOC. 1 & 0 & 0 & 0 & 0 \\
\hline A3040 & 318 LOC. 2 & 0 & 0 & 0 & 0 \\
\hline A3041 & 318 LOC. 3 & 0 & 0 & 0 & 0 \\
\hline A3042 & 320 LOC. 1 & 0 & 0 & 0 & 0 \\
\hline A3043 & 320 LOC. 2 & 0 & 0 & 0 & 0 \\
\hline A3044 & 331 LOC. 1 & 0 & 0 & 0 & 0 \\
\hline A3045 & 331 LOC. 2 & 0 & 0 & 0 & 0 \\
\hline A3046 & 331 LOC. 3 & 0 & 0 & 0 & 0 \\
\hline A3047 & 3720 LOC. 1 & 0 & 0 & 0 & 0 \\
\hline A3048 & 3720 LOC. 2 & 30 & 60 & 30 & 120 \\
\hline A3049 & 3730 LOC. 1 & 70 & 40 & 0 & 110 \\
\hline A3050 & 3745 LOC. 1 & 0 & 0 & 0 & 0 \\
\hline A3051 & 3745A LOC. 1 & 0 & 0 & 0 & 0 \\
\hline A3052 & 3745B LOC. 1 & 0 & 0 & 0 & 0 \\
\hline A3053 & 3746 LOC. 1 & 0 & 0 & 0 & 0 \\
\hline A3054 & 3746A LOC. 1 & 0 & 0 & 0 & 0 \\
\hline A3055 & 3708 LOC. 1 & 0 & 0 & 0 & 0 \\
\hline A3056 & 324 LOC. 1 & 0 & 0 & 0 & 0 \\
\hline A3057 & 324 LOC. 2 & 0 & 0 & 0 & 0 \\
\hline A3058 & 324 LOC. 3 & 0 & 0 & 0 & 0 \\
\hline A3059 & 324 LOC. 4 & 0 & 0 & 0 & 0 \\
\hline A3060 & 324 LOC. 5 & 0 & 0 & 0 & 0 \\
\hline A3061 & 325 LOC. 1 & 0 & 0 & 0 & 0 \\
\hline A3062 & 325 LOC. 2 & 0 & 20 & 0 & 20 \\
\hline A3063 & 325 LOC. 3 & 0 & 0 & 0 & 0 \\
\hline A3064 & 326 LOC. 1 & 0 & 0 & 0 & 0 \\
\hline A3065 & 326 LOC. 2 & 0 & 0 & 0 & 0 \\
\hline A3066 & 326 LOC. 3 & 0 & 0 & 0 & 0 \\
\hline A3068 & 326 LOC. 5 & 0 & 0 & 0 & 0 \\
\hline
\end{tabular}


Appendix D

Area Monitoring TLD Results for CY $1994^{(a)}$

\begin{tabular}{|c|c|c|c|c|c|}
\hline & & 1st Quarter & 2nd/3rd Quarters & 4th Quarters & Annual \\
\hline TLD ID\# & TLD Location & Deep Dose (mrem) & Deep Dose (mrem) & Deep Dose (mrem) & Deep Dose (mrem) \\
\hline A3069 & 327 LOC. 1 & 0 & 0 & 0 & 0 \\
\hline A3070 & 327 LOC. 2 & 50 & 50 & 30 & 130 \\
\hline A3071 & 329 LOC. 1 & 0 & 0 & 0 & 0 \\
\hline $\mathrm{A} 3072$ & 329 LOC. 2 & 0 & 0 & C & 0 \\
\hline $\mathrm{A} 3073^{(\mathrm{C})}$ & 336-1 LOC. 1 & 0 & 0 & 0 & 0 \\
\hline $\mathrm{A3074}$ & 329 LOC. 4 & 20 & 50 & 50 & 120 \\
\hline A3075 & 329 LOC. 5 & 0 & 0 & 0 & 0 \\
\hline A3076 & 3760 TRL. 2 & 0 & 0 & 0 & 0 \\
\hline A3077 & 329 TRL.4 & 0 & 0 & 0 & 0 \\
\hline A3078 & 329 TRL. 5 & 0 & 0 & 0 & 0 \\
\hline A3079 & 329 TRL. 6 & 0 & 0 & 0 & 0 \\
\hline$A 3080$ & 337 LOC. 1 & 0 & 0 & 0 & 0 \\
\hline A3081 & 337 LOC. 2 & 0 & 0 & 0 & 0 \\
\hline A3082 & 337 LOC. 3 & 0 & 0 & 0 & 0 \\
\hline A3083 & 337 LOC.4 & 0 & 0 & 0 & 0 \\
\hline A3084 & 337 LOC. 5 & 0 & 0 & 0 & 0 \\
\hline A3085 & 337 LOC. 6 & 0 & 0 & 0 & 0 \\
\hline A3086 & 622R LOC. 1 & 0 & 0 & 0 & 0 \\
\hline A3087 & 622R LOC.2 & 0 & 0 & 0 & 0 \\
\hline A3088 & 747A LOC. 1 & 0 & 0 & 0 & 0 \\
\hline A3089 & 747A Tri LOC.1 & 0 & 0 & 0 & 0 \\
\hline A3090 & 747A Trl LOC. 2 & 0 & 0 & 0 & 0 \\
\hline A3091 & ESB LOC.1 & 0 & 0 & 0 & 0 \\
\hline A3092 & ESB LOC. 2 & 0 & 0 & 0 & 0 \\
\hline A3093 & LSL-II LOC. 1 & 0 & 0 & 0 & 0 \\
\hline A3094 & LSL-|| LOC. 2 & 0 & 0 & 0 & 0 \\
\hline A3095 & LSL-11 LOC. 3 & 0 & 0 & 0 & 0 \\
\hline A3096 & LSL-II LOC.4 & 0 & 0 & 0 & 0 \\
\hline A3097 & LSL-11 LOC. 5 & 0 & 0 & 0 & 0 \\
\hline A3098 & LSL-II LOC. 6 & 0 & 0 & 0 & 0 \\
\hline A3099 & PSL LOC.1 & 0 & 0 & 0 & 0 \\
\hline A3100 & PSL LOC. 2 & 0 & 0 & 0 & 0 \\
\hline A3101 & PSL LOC. 3 & 0 & 0 & 0 & 0 \\
\hline A3102 & PSL LOC. 4 & 0 & 0 & 0 & 0 \\
\hline A3103 & PSL LOC.5 & 0 & 0 & 0 & 0 \\
\hline
\end{tabular}




\section{Appendix D}

Area Monitoring TLD Results for CY $1994^{(a)}$

\begin{tabular}{|c|c|c|c|c|c|}
\hline & & 1st Quarter & 2nd/3rd Quarters & 4th Quarters & Annual \\
\hline TLD ID\# & TLD Location & Deep Dose (mrem) & Deep Dose (mrem) & Deep Dose (mrem) & Deep Dose (mrem) \\
\hline A3105 & RTL LOC.1 & 0 & 0 & 0 & 0 \\
\hline A3106 & RTL LOC. 2 & 0 & 0 & 0 & 0 \\
\hline A3107 & RTL LOC. 3 & 0 & 0 & 0 & 0 \\
\hline A3108 & RTL LOC.4 & 0 & 0 & 0 & 0 \\
\hline$A 3109$ & RTL LOC.5 & 0 & 0 & 0 & 0 \\
\hline$A 3110$ & RTL LOC.6 & 0 & 0 & 0 & 0 \\
\hline A3111 & Saint LOC. 1 & 0 & 0 & 0 & 0 \\
\hline A3113 & 2400 LOC. 1 & 0 & C & 0 & 0 \\
\hline A3114 & 2400 LOC. 2 & 0 & 0 & 0 & 0 \\
\hline $\mathrm{A3115}$ & 2400 LOC. 3 & 0 & 0 & 0 & 0 \\
\hline A3116 & 2400 LOC. 4 & 0 & 0 & 0 & 0 \\
\hline A3117 & ALE LOC.1 & 0 & 0 & 0 & 0 \\
\hline$A 3118$ & ALE LOC. 2 & 0 & 0 & 0 & 0 \\
\hline \multirow[t]{2}{*}{ A3119 } & 3718-G & (d) & (d) & 40 & 40 \\
\hline & & \multicolumn{4}{|c|}{ SPECIAL AREA TLDs } \\
\hline $\mathrm{A} 3104^{(\mathrm{e})}$ & 325 LOC. 4 & 490 & 260 & 180 & 930 \\
\hline & & & & & \\
\hline \multicolumn{6}{|c|}{ (a) Multiply area TLD results by 0.23 to obtain dose estimates corrected for worker occupancy. } \\
\hline \multicolumn{6}{|c|}{\begin{tabular}{|l|l|l|l|l|} 
(b) Dosimeter was lost. & & & & \\
\end{tabular}} \\
\hline \multicolumn{6}{|c|}{ (c) 329 LOC. 3 was identified as A3073 during CY 93, discontinued in CY 94, and designator was assigned to $336-1$ LOC.1 } \\
\hline \multicolumn{6}{|c|}{\begin{tabular}{|l|l|l|} 
(d) Not initiated until 4th quarter of CY 94. & &
\end{tabular}} \\
\hline \multicolumn{6}{|c|}{ (e) During CY 93, A3104 was referred to as A3112. } \\
\hline
\end{tabular}




\section{Distribution}

No. of

Copies

Offsite

2 DOE/Office of Scientific and

Technical Information

Onsite

DOE Richland Operations Office

D.L. Rice, A5-55

26

Pacific Northwest National Laboratory

W.J. Apley, P7-75

S.G. Barrett, P7-28

S.R. Bivins, P8-49

G.D. Buckley, P7-28

V.L. Berndt, A3-60
No. of

Copies

T.D. Eaton, P7-39

J.J. Fix, P7-02

P.J. Gaither, P7-28

D.P. Higby, P7-68

W.A. Hoober, P8-24

J.D. Hudspeth, P7-78

J.D. Jacobsen, P7-78

S.L. Keller, P7-78

D.E. Knowlton, P7-35

S.J. Kostorowski, P8-10

L.E. Maples, P7-39

K.H. Pryor, P7-78

B.A. Rathbone, P7-02

R.D. Sharp, P8-20

G.A. Stoetzel, P7-78

F.J. Wade, P8-24

Technical Report Files (5)

Distr.1 
. 